ISSN:

Print - $2277-0755$

Online - $2315-7453$

(c) FUNAAB 2017

\title{
COMPARATIVE EVALUATION OF SODOM APPLE EXTRACT AND LEMON JUICE AS VEGETABLE COAGULANTS IN THE MAN UFACTURE OF HOME MADE CHEESE
}

\author{
S.S. ABIOLA, *0.0. ADEWUMI, M.OYAWALE AND O.F.TAKUNBE \\ Department of Animal Production and Health, Federal University of Agriculture, \\ Abeokuta, Nigenia \\ *Comesponding Author: badewumi2003@yahoo.comＴel: 2348034822547
}

\begin{abstract}
ABST RACT
An experiment was carried out to compare the quality characteristics of cheese produced using Sodom apple and Lemon juice as plant coagulants. The weight of cheese produced from $1000 \mathrm{ml}$ of milk with $100 \mathrm{ml}$ of Sodom apple extract was $215.5 \mathrm{~g}$ while $134.4 \mathrm{~g}$ of cheese was obtained when Lemon juice was used. The volume of whey obtained using Sodom apple extract was $864.6 \mathrm{ml}$ while Lemon juice produced $939.3 \mathrm{ml}$ of whey. The average $\mathrm{pH}$ of Sodom apple cheese was 6.36 while that of lemon juice cheese produced using Lemon juice was 5.16. Proximate analysis revealed that Sodom apple cheese had crude protein content of $22.00 \%$ significantly $(p<0.05)$ lower than Lemon juice cheese of 29.33\%. Ether extract content for Sodom apple cheese was $19.00 \%$ while that of Lemon juice was $28.67 \%$. The ash content of the cheese was $9.67 \%$ while $7.67 \%$ for Sodom apple and Lemon juice cheese respectively. The moisture content for Sodom apple cheese was $60.00 \%$ while that of Lemon juice was $46.67 \%$. The mineral analysis revealed that cheese produced from Lemon juice was higher in sodium, potassium, phosphorus and selenium compared to cheese produced from Sodom apple. Cheese produced from Sodom apple extract had higher refrigeration weight loss of $2.80 \%$. It can be concluded that cheese produced from Lemon juice was superior in nutrient content: sodium, potassium, phosphorus and selenium and storage stability compared to the cheese obtained from Sodom apple extract.
\end{abstract}

Keywords: Cheese, Sodom apple extract, Lemon juice, Vegetable Coagulants.

\section{INTRODUCTION}

Cheese is an important dairy product and an integral part of a healthful diet due to its substantial contribution to human health. It is an excellent source of protein, fat and minerals such as calcium, iron and phosphorus, vitamins and essential amino acids and therefore its an important food in the diet of both young and old people (O 'Connor, 1993). It is especially good for the bone of children, elderly people, and pregnant lactating women for strengthening bone and cartilage (O 'Connor, 1993). Cheese is a rich source of bioactive peptides which have a positive influence on hypertension, although their effect is less pronounced than what has been observed with drugs based on the same principle (Li, 2007).

Cheese is made in almost every country of 
the world and there exists more than 2000 varieties. D espite the large number of varieties, cheese may be classified into different groups, i.e ripened and unripened cheese, cheese with low or high fat content and cheese with soft or hard consistency. The basic reason for purposely processing milk into cheese is to preserve a perishable food and to convert it into a stable and storable product. It also expands the variety of food (Vedamuthu and Washam, 1983). Unprocessed milk held at high ambient temperatures has a shelf life from 2-3 hours up to 24hours. Cheese, however, has a shelf life from 4-5 days up to five years depending on the variety (Vedamuthu and Washam, 1983). Production of cheese is dynamic on the time, temperature, the bacterial culture (lactic acid bacteria) and coagulating enzyme that are used to concentrate and separate the casein (milk protein) and fat from the whey (Fox \&al. 2000).

The most important coagulant used in the production of cheese in Nigeria is obtained from Calctropis procera (Sodom apple). The lemons are a type of berry called hesperidium. They grow in sub-tropical and tropical; areas (Morton, 1987). There is need to know the potentials of other coagulant such as Citnuslimm(Lemon juice) in the manufacture of home-made cheese Therefore, the aim of this study was to determine quality of home-made cheese produced from cattle milk using two types of plant coagulants (Sodom apple extract and Lemon juice).

\section{MATERIALS AND METHODS}

The experiment was carried out in the Animal Product Processing Laboratory, Department of Animal Production and Health, Federal University of Agriculture, Abeokuta, Nigeria which falls within the rainforest region with a typical hot and humid climate. The region is $76 \mathrm{~m}$ above sea level, lies at latitude $701349.4^{\prime \prime} \mathrm{N}$ and longitude 3026 $11.98^{\prime \prime} \mathrm{E}$. The climate is humid with mean annual precipitation, temperature and relative humidity of $1,112.11 \mathrm{~mm}, 34{ }^{\circ} \mathrm{C}$ and $80 \%$ respectively.

\section{EXPERIMENTAL PROCEDURE}

Sodom apple and Lemon were obtained from Kotopo and Kuto, Nigeria, O gun State. Fresh milk was collected from White Fulani cattle obtained from the cattle unit of Directorate of University Farms, Federal University of Agriculture, A beokuta, Nigeria. Fresh milk sample (1 litre) was collected from White Fulani breed of cattle. The milk was taken to the laboratory where the $\mathrm{pH}$ was determined using a digital $\mathrm{Ph}$ meter, uk 3015 D unmiu Essex England. The weight was taken after 24 hours to determine any refrigeration weight loss. Each portion of cow milk was boiled over an electric cooker. Fresh Sodom apple was prepared by crushing $60 \mathrm{~g}$ of the leaves and the extract added to warm milk for 5 minutes to allow the enzymes in the leaves to react with the milk. Fresh Lemon fruits were squeezed very carefully to avoid any contamination and screened through a $8.5 \mathrm{~mm}$ sieve to obtain the juice. One litre of milk was poured into each pot (A and B).The milk in the pot was heated to approximately $50^{\circ} \mathrm{C}$ in about 30 40min. The extract of Sodom apple and Lemon juice $(100 \mathrm{ml}$ each) was then added separately to the heated milk and stirred intermittently until boiling point and coagulation (curd formation:visible separation into cheese and whey). The loose curds were poured into $8.5 \mathrm{~mm}$ sieve to facilitate whey drainage and also to mold into shape. The flow chart for the recipe is shown in figure 1 below. 
Fresh cow milk (1 liter each) in Pots A and B Heat (500C)

Coagulation point

\author{
Coagulants
}

Add Sodom apple extract in pot A and Lemon Juice in pot B

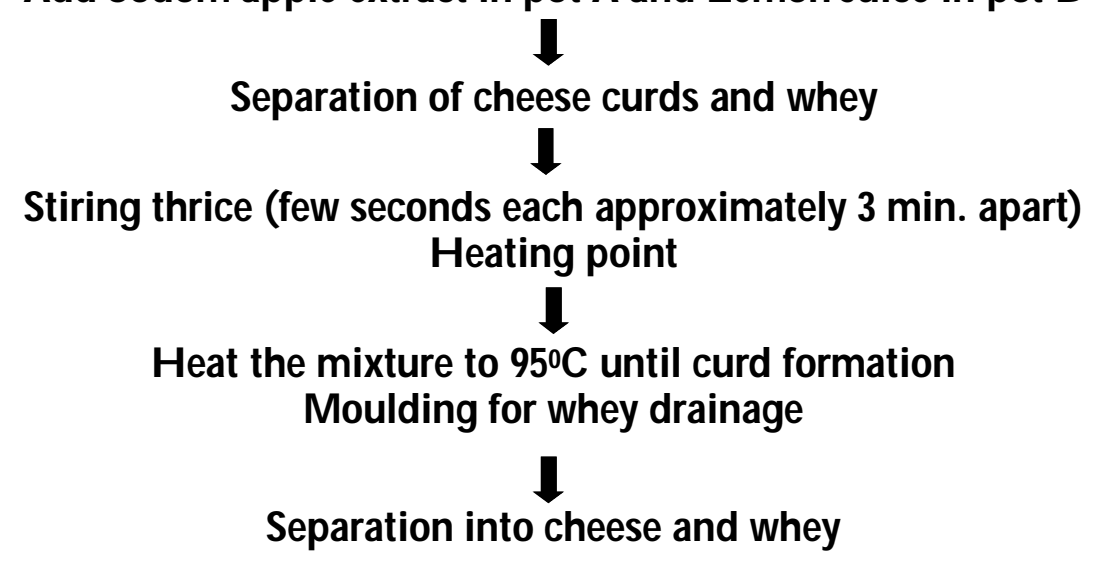

Proximate analysis such as crude protein, ether extract, ash and moisture were also carried out on the cheese samples according to AOAC. (2000). The mineral contents (phosphorus, magnesium, sodium, potassium and selenium) of the cheese produced were also determined. Atomic absorption spectrophotometer was used to determine the mineral elements content in the Central Laboratory of the Biotechnology of FUNAAB. Means were analyzed using the stu-

\title{
RESULTS AN D DISCUSSION
} Yield of Cheese obtained

Sodom apple cheese had a weight of $215.5 \mathrm{~g}$ while lemon cheese was $134.4 \mathrm{~g}$ as presented in Table 1. The higher values of cheese weight whe compared with cheese weight obtained from Lemon juice could be due to different chemical composition of the plant coagulants used. This result agrees with the report of Akinloye and Adewumi, (2014). dent T-test at 5\% significant level SAS (1999).

Table 1: Yield and pH of cheese produced with Sodom apple extract and Lemon juice

\begin{tabular}{lll}
\hline Parameters & \multicolumn{2}{c}{ Cheese } \\
& Sodom apple extract & Lemon juice \\
\hline Weight of cheese $(\mathrm{g})$ & 215.5 & 134.4 \\
Volume of whey $(\mathrm{ml})$ & 864.6 & 939.3 \\
pH of whey & 6.26 & 4.02 \\
pH of cheese & 6.36 & 5.16 \\
\hline
\end{tabular}




\section{Volume of whey obtained}

Volume of whey obtained from Sodom apple cheese was $864.6 \mathrm{ml}$ while that of lemon cheese was $939.3 \mathrm{ml}$. The difference could be due to effect of citric acid of the Lemon juice on casein of milk which caused smaller part of the milk to shrink thereby yielding a lot of whey. On the contrary, the proteolytic enzyme in Sodom apple probably caused most of the milk to curdle thereby producing less whey.

\section{$\mathrm{pH}$ of Cheese}

The $\mathrm{pH}$ of Sodom apple cheese was 6.36, while that of lemon cheese was 5.16. The difference could be due to the citric acid in lemon which made the cheese to be acidic, while the proteolytic enzyme in Sodom apple made the cheese to be alkaline. The $\mathrm{pH}$ of Sodom apple cheese recorded in this study is higher than the value reported by Vaboi-Egbeni (2010) who introduced starter culture and fermented the cheese while Adetunji and Babalobi (2011) inoculated the cheese with bacteria.

\section{Proximate composition of Cheese}

The moisture content of Sodom apple cheese $(60.00 \%)$ was higher than for cheese processed with Lemon juice cheese of $46.67 \%$. The higher moisture content from Sodom apple could be attributed to the coagulating material. Although, this result is in contrast with the result of 0 motosho $\&$ al (2011) who reported 51\% moisture content in cheese produced from Sodom apple, it is, however, similar to the result of Adegoke $\boldsymbol{A}$ al. (1992) who reported $61.70 \%$ moisture content in cheese produced from Sodom apple. Variation in moisture content of cheese could be attributed to the coagulating strength of the leaves of the plant which may be obtained under different methods and environment. It must be noted that higher moisture content is not preferred because it could favour the growth and proliferation of micro-organisms that reduces the shelf life of cheese (Adegoke $\notin \mathrm{al}, 1992)$. This is similar to the findings of Akinloye and Adewumi (2014) who reported that Lemon juice had been found to have the strongest coagulating ability when compared to Sodom apple and Carica papaya extract. The crude protein content of Sodom apple cheese $(22.00 \%)$ was lower than that of Lemon juice of 29.33\% (Table 2). The protein obtained from this study was higher than the value recorded by Adetunji and Babalobi (2011) who reported 20.78\% for cheese produced using Sodom apple. This could be due to the higher dry matter content of the cheese obtained from Lemon juice. However, the result is comparable to that of O motosho \&al., (2011), Adetunji and Salawu (2008) who reported values of $25.56 \%$ and $33.84 \%$ respectively. Sodom apple cheese had a lower crude fat of $19.00 \%$ than that of Lemon juice (28.67\%). The fat in Sodom apple cheese is within the range of $11.2 \%-21.9 \%$ as reported by Ogundiwin and Oke (1982) and similar to that of Uzeh \& al (2006) who reported $18.55 \%$. The percentage ash in Sodom apple cheese was 9.67\% while that of Lemon juice cheese was $7.67 \%$.

\section{Table 2: Proximate composition (\%) of homemade cheese produced using from Sodom apple extract and Lemon juice}


COMPARATIVE EVALUATION OF SODOM APPLE EXTRACT ...

Table 2: Proximate composition (\%) of homemade cheese produced using from Sodom apple extract and Lemon juice

\begin{tabular}{lll}
\hline Parameters (\%) & \multicolumn{3}{c}{ Cheese } \\
& Sodom apple extract & Lemon juice \\
\hline Crude protein & $22.00 \pm 2.65 \mathrm{~b}$ & $29.33 \pm 0.58 \mathrm{a}$ \\
Ether extract & $19.00 \pm 2.00$ & $28.67 \pm 1.15$ \\
Ash & $9.67 \pm 2.89$ & $7.67 \pm 2.52$ \\
Moisture & $60.00 \pm 2.00$ & $46.67 \pm 1.53$ \\
\hline
\end{tabular}

a,b means in the same row with different superscripts are significantly different $(p<0.05)$

\section{Mineral composition of Cheese}

Mineral composition of Cheese from Sodom apple and Lemon juice was statistically similar $(\mathrm{p}<0.05)$. The Sodium content of Sodom apple cheese was $0.11 \%$ while lemon cheese had a value of $0.19 \%$. O motosho e al (2011) reported the sodium content in apple cheese to be $16.98 \%$ while Adetunji and Babalobi (2011) reported the sodium content of Sodom apple cheese to be $0.24 \%$, while lemon cheese apple had a value of $0.19 \%$. O motosho \& al, (2011) reported Potassium content of Sodom apple to be $22.5 \%$ while Adetunji and Babalobi (2011) reported the Potassium content of Sodom apple to be $0.16 \%$ (Table 3). Calcium con- tent of Sodom apple was $0.27 \%$ while lemon cheese had a value of $0.41 \%$. The calcium content obtained in this work was higher than the value reported by Omotosho $\mathrm{A} \mathrm{al}$. (2011) and Adetunji and Babalobi (2011). Conversely, Adewumi and Akinloye, 2016 observed a lower calcium in cheese obtained from Sodom apple. This may be due to the low protein content in milk. Adewumi \& al. (2016). Adetunji and Babalobi (2011) reported $0.71 \%$ phosphorus content of Sodom apple while lemon cheese had a value of $0.93 \%$. Selenium content of Sodom apple was $2.52 \%$, while lemon cheese had a value of $3.50 \%$.

Table 3: Mineral composition of cheese produced from Sodom apple extract and Lemon juice

\begin{tabular}{lll}
\hline Parameters & (\%) & \multicolumn{2}{c}{ Cheese } \\
& Sodom apple extract & Lemon juice \\
\hline Sodium & $0.11 \pm 0.02$ & $0.19 \pm 0.02$ \\
Potassium & $0.24 \pm 0.01$ & $0.34 \pm 0.01$ \\
Calcium & $0.27 \pm 0.00$ & $0.17 \pm 0.19$ \\
Phosphorus & $0.71 \pm 0.00$ & $0.93 \pm 0.01$ \\
Selenium & $2.52 \pm 0.00$ & $3.50 \pm 0.21$ \\
\hline
\end{tabular}

Means in the same row are not significantly different 


\section{Storage stability of Cheese}

The weight loss of cheese produced with Lemon juice was $0.98 \%$ after 24hours of storage while the Sodom apple had weight loss of $2.80 \%$ (Table 4$)$. The result obtained from the Sodom apple cheese does not support the finding of Yunusa (2011) who reported that the cheese produced using Sodom apple was stable upon refrigeration after 24 hours.

Table 4: Storage stability of home -made cheese produced from Sodom apple extract and Lemon juice

\begin{tabular}{lll}
\hline Parameters & \multicolumn{2}{c}{ Cheese } \\
& Sodom apple extract & Lemon juice \\
\hline Initial weight $(\mathrm{g})$ & $15.33 \pm 5.29$ & $9.40 \pm 2.52$ \\
Final weight $(\mathrm{g})$ & $14.93 \pm 5.19$ & $9.03 \pm 2.44$ \\
Weight loss $(\mathrm{g})$ & $0.43 \pm 0.15$ & $0.10 \pm 0.10$ \\
Weight loss $(\%)$ & $2.80 \pm 0.00 \mathrm{a}$ & $0.98 \pm 0.86 \mathrm{~b}$ \\
\hline
\end{tabular}

$\mathrm{a}, \mathrm{b}$ mean in the same row with different superscripts are significantly different $(\mathrm{p}>0.05)$

\section{CONCLUSION}

Cheese obtained using Lemon juice had higher crude protein content. However, since there was no significant difference in the yield of both cheeses, it could be concluded that Lemon juice and Sodom apple juice can be used as plant coagulants in the production of home-made cheese without adverse effect on the quantity.

\section{REFERENCES}

AOAC (Association of Analytical Chemists). 2000. Official methods of analysis. 15th Ed. AOAC, Washington, D C. USA.

Adegoke, G.0, Nse, E.N., Akanni, 0.0. 1992. Effects of heat, processing time and $\mathrm{pH}$ on microflora, aflatoxin content and storability of 'wara', a soft, white cheese. Die Nahnug 36:259-264.

Adetunji, V.0., Babalobi 0.0. 2011. Comparative assessment of the nutritional contents of "wara" a West Africa soft cheese using C. procera and Cymbopogn atratus as coag ulants African Jaumal of Food, Agriculture, Nur trition andDedqumett 11(7):5573-5585.

Adetunji, V.0., Salawu , 0.T. 2008. West African soft cheese "wara" processed with Caldropis proeera and Carica papaya: A comparative assessment of nutritional values AfricanJaumal of Bidtechndogy 7(18): 3360-3362.

FAO 1990. The technology of traditional product indeveloping countries. Food and Agricultural Organisation of the United Nations, Italy.

Fox, P.F., Guinee, T.P., Logan, T.M., Sweeney. P.L.H. 2000, "Fundamentals of cheese science", Aspen Publisher, Inc. Gaithersburg, MD .

Igyor, M.A. Igbian, E.K., Iombo, C.I. 2006. Effects of soymilk supplement on the 
COMPARATIVE EVALUATION OF SODOM APPLE EXTRACT ...

yield and Quality of 'Warankashi' Nigerian coagulants on the nutritive value, in-vitro FodJaumal 24: 92-97. digestibility and sensory properties of wara cheese. Intemational Jaumal of Dairy Saiene 6:

Li, G.H., Le, G.W., Shi, Y.H., Shretha, 58-65.

S., 2007. Angiotensin I-converting enzyme inhibitory peptides derived from food young adults. Intemational Joumal of Obsterics 31:1688-1695.

Vedamuthu, E.R., Washam, C. 1983. In: Reed G. (Ed). Biotechnology, VelagChemie, Wënhim G ermany.

Morton, J. 1987. Lemon p. 160-168.In: Yunusa, A.J. 2011. Quality characteristics of Fruits of warm climates. Florida Flair cheese produced from three breeds of cattle Books, Miami. http// wuwhat.purdue edu/ new in Nigeria. D epartment of Animal Science, cop/ motan/ banahtm.

Kabba College of Agriculture, Kabba, Kogi State. Nigerian. Jaumal of Environmental Issues O'Connor, C.B. 1993. Traditional Cheese andAgialtureinDedopingCantries 3(3): 95Making Manual. ILCA (International Livestock Center for Africa), Addis Ababa, Ethiopia. 43 PP.

Ogundiwin, J.0., Oke, O.L 1983. Factors affecting the processing of 'WARA' Nigeria white cheese. Fooddhemistry, 11: 1-4. Edition. SAS Inst., Inc., Cary, NC.

Omotosho, O.E., Oboh, G., Iweala,

E.E.J. 2011. Comparative effect of local

(Manuscipt reecived 25th May, 2016; accepted: 30th Oddber, 2018). 